\title{
СТОАКНОВЕНИЕ ЦИВИАИЗАЦИЙ
}

\section{Байректаревич А.}

\section{EUROPE - THE LETZTE MENSCH OR ÜBERMENSCH, THE NEW BYZANTIUM OR DECLINING ROME}

Review. A freshly released IMF's World Economic Outlook brings (yet again, for the sixth year in a row, and for the third time this year only) no comforting picture to anyone within the G-7, especially in the US and EU. Will the passionately US-pushed cross-Atlantic Free Trade Area save the day? Or, would that Pact-push drag the things over the edge and mark an end of the unionistic Europe? Is the extended EU conflict with Russia actually a beginning of the Atlantic-Central Europe's conflict over Russia, an internalization of mega geopolitical and geo-economic dilemma - who accommodates with whom, in and out of the Union? Methodological basis of the research are systemic, structural and functional, and comparative istorichseky kultkrno-civilizational approaches, methods of analysis, synthesis, simulation. Finally, does more Ukrainian (and Eastern Europe) calamities pave the road for a new cross-continental grand accommodation, of either austerity-tired France or über-performing Germany with Russia, therefore the end of the EU? For whose sake Eastern Europe has been barred of all important debates such as that of Slavism, identity, secularism and antifascism? Why do we suddenly wonder that all around Germany-led Central Europe, the neo-Nazism gains ground while only Russia insists on antifascism and (pan-)Slavism?

Keywords: international relations, foreign politics, политические конфликты, Byzantium, Europe, Slavism, hitory, nation, interests, security.

Аннотация. Свежий доклад МВФ о мировой экономике (уже шестой год подряд и третий раз за последний год) принес дурные вести для членов Большой семерки - и в особенности для США и Евросоюза. Спасет ли ситуацию столь рьяно продвигаемая США межатлантическал зона свободной торговли? Илиже такое давление опрокинет единую Европу? Является ли продлеваемый конфликт ЕС и России началом конфликта Атлантической зоны с иентральной Европой по поводу России в рамках глобальной геоэкономической дилеммы выбора долговременных партнеров? Методологическую основу исследования составляют структурный, функциональный и сравнительно-исторический, культурноизвилизационный подходы, методы анализа, синтеза, модемирования. Приведет ми кризис Украины (и восточной Европы) к новому великому континентальному союзу уставиий от экономии Франции или трудящейся в поте мица Германии с Россией, тем самым положив конеи Евросоюзу? По чвей воле 
восточнал Европа отгорожена от участия в важных спорах на темы Славлнства, идентичности, светского государства и антифашизма? Почему же мы удивляемся, ито во всей иентральной Европе, сосредоточенной вокруг Германии, нео-нацизм укрепляет позиции, в то время, как мишь Россия защищает позиции антифашизма и (пан-) Славянства?

Ключевые слова: международные отношения, внешнял политика, political conflicts, Византия, Европа, славизм, история, начия, интересы, безопасность.

B efore answering that, let us examine what is (the meaning and size of) our Europe? Where, how and - very importantly when is our Europe? For example, is the non-EU Europe the existent but invisible world, sort of the dark side of the moon? Or, is that more? Beyond the ancient Maastricht and Schengen: the Roman Hadrian Wall and Limes Line there was no world at all. There was only (an instrument of) the Silk Road - that antique WTO, isn't it? Hence, is this unionistic condominium the best of Europe, or Europe itself?

Is the EU an authentic post-Westphalian conglomerate and the only logical post-Metternich concert of different Europes, the world's last cosmopolitan enjoying its postmodern holiday from history? ${ }^{1}$ Is that possibly the lost Atlántida or mythical Arcadia- a Hegelian end of history world? Thus, should this OZ be a mix of the endemically domesticated Marx-Engels grand utopia and Kennedy's dream-world "where the weak are safe and the strong are just"? Or, is it maybe as Charles Kupchan calls it a 'postmodern imperium'? Something that exhorts its well-off status quo by notoriously exporting its transformative powers of free trade dogma and human rights stigma ${ }^{2}-a$

\footnotetext{
${ }^{1}$ One of the greatest historians of our age, Sir Toynbee, gives an interesting account of our civilizational vertical. $\mathrm{He}$ clas-sifies as many as nineteen major civilizations: Egyptian, Andean, Sinic, Minoan, Sumerian, Mayan, Indic, Hittite, Hellenic, Western, Orthodox Christian/Russian, Far Eastern, Orthodox Christian/main body, Persian, Arabic, Hindu, Mexican, Yucatec, and Babylonic. Further on, there are as he calls them - four abortive civilizations (Far Western Christian, Far Eastern Christian, Scandinavian, Syriac) and five arrested civilizations (Polynesian, Eskimo, Nomadic, Ottoman, Spartan). Like to no other continent, majority of them are related (originating from or linked) to European proper.

${ }^{2}$ Lately, it looks like a Gay-rights Jihad at many places. The non-selective, but massive push without premeditation on the key issue here: whether homosexuality should be either tolerated behavior or promoted life-style, has to be urgently
}

modified continuation of colonial legacy when the European conquerors, with fire and sword, spread commerce, ${ }^{3}$ Christianity and civilization overseas - a kind of 'new Byzantium', or is that more of a Richard Young's declining, unreformed and rigid Rome? Hence, is this a post-Hobbesian (yet, not quite a Kantian) world, in which the letzte Mensch expelled Übermensch? Could it be as one old graffiti in Prague implies: $\mathrm{EU}=\mathrm{SU}^{2}$ ? Does the EU-ization of Europe equals to a restoration of the universalistic world of Rome's Papacy, to a restaging of the Roman-Catholic Caliphate? Is this Union a Leonard's runner of the $21^{\text {st }}$ century, or is it perhaps Kagan's 'Venus'- gloomy and opaque world, warmer but equally distant and unforeseen like 'Mars'?

Is this Brussels-headquartered construct, the $20^{\text {th }}$ century's version of Zollverein with standard-

revisited and (re-)calibrated. As it stands now, this Gay-rights Jihad serves neither the human/behavioristic rights nor a worrying birth-rates decline. The European demographics is far more of a serious and urgent socio-economic problem. Why? It is closely related to the emotional-charge inflammable triangular issues - identity, migration and integration, and by it triggered (to say: justified) right-wing anti-politics.

${ }^{3}$ Is globalization the natural doctrine of global hegemony? Well, its main instrument, commerce -as we know - brings people into contact, not necessarily to an agreement, even less to mutual benefits and harmony... Or, "If goods cannot cross borders, armies will" is the famous saying of the XIX century French economist Frederic Bastiat, so often quoted by the longest-ever serving US Secretary of State Cordell Hull.

4 "No venue has been created in which an EU-wide public opinion might be formed... European Parliament elections are not truly European because they are 27 different elections with different electoral systems after campaigns in which national issues predominate... Under present procedures, both the President of the European Commission and the President of the European Council are selected in private meetings of heads of governments..", says former Irish Prime Minister John Bruton. Bruton, J. (2013), How real is the danger of an EU collapse?, EU Journal Europe's World 23(13) 2013, Brussels 
ized tariffs and trade, but of an autonomous fiscal policy and politics? Thus, is the EU a political and economic re-approachment of sovereign states or maybe just an(other) enterprise of the borderless financial capital? Ergo, would that be a pure construct of financial oligarchy whose invisible hand tacitly corrupted the Maastricht Treaty as to web-up a borderless, limitless, wireless and careless power hub, while at the same time entrenching, silencing and rarefying labour within each nation state?

Is this a supersized Switzerland (ruled by the cacophony of many languages and enveloped in economic egotism of its self-centered people), with the cantons (MS, Council of EU) still far more powerful than the central government (the EU Parliament, Brussels' Commission, ECJ), while Swiss themselves -although in the geographic heart of that Union - stubbornly continue to defy any membership. Does it really matter (and if so, to what extent) that Niall Ferguson wonders: "... the EU lacks a common language, a common postal system, a common soccer team (Britain as well, rem. A.B.) even a standard electric socket...”? Kissinger himself was allegedly looking for a phone number of Europe, too. Baron Ridley portrayed the Union as a Fourth Reich, not only dominated by Germany, but also institutionally Germanized. Another conservative Briton, Larry Siedentop, remarked in his Democracy in Europe that it is actually France who is running the EU 'show', in the typical French way - less than accountable bureaucracy that prevents any evolution of the European into an American-style United States. Thus, Siedentop's EU is more of a Third Bonapartistic Empire than possibly a Fourth German Reich. The Heartland or Rimland?

After all, is the Union yet another virtue out of necessity, as Brzezinski claimed, that after centuries of colonial overstretch and of mutual destructions (between protagonists in close geographic proximity), Europe irreversibly lost its demographic, economic and politico-military importance, and that the early EU was more of an attempt to rescue a nation state than it was the quest for a true enterprise of the European Community building?

Despite different names and categorizations attached, historical analogies and descriptions used, most scholars would agree upon the very geopolitical definition of the EU: Grand re-approachment of France and Germany after WWII, culminating in the Elysée accords of 1961. An interpretation of this instrument is rather simple: a bilateral peace treaty through achieved consensus by which Germany accepted a predominant French say in political affairs of EU/Europe, and France — in return - accepted a more dominant German say in economic matters of EU/Europe. All that tacitly blessed by a perfect balancer-Britain, attempting to conveniently return to its splendid isolation from the Continent in the post-WWII years. Consequently, nearly all scholars would agree that the Franco-German alliance actually represents a geopolitical axis, a backbone of the Union.

However, the inner unionistic equilibrium will be maintained only if the Atlantic-Central Europe skillfully calibrates and balances its own equidistance from both assertive Russia and the omnipresent US. Any alternative to the current Union is a grand accommodation of either France or Germany with Russia. This means a return to Europe of the $18^{\text {th }}, 19^{\text {th }}$ and early $20^{\text {th }}$ centuries - namely, direct confrontations over the Continent's core sectors, perpetual animosities wars and destructions. Both Russia and the US has demonstrated ability for a skillful and persistent conduct of international affairs, passions and visions to fight for their agendas. It is time for Brussels to live up to its very idea, and to show the same. Biology and geopolitics share one basic rule: comply or die.

\section{БИБАИОГРАФИЯ}

1. Anis H. Bajrektarevic. Is There Life after Facebook? New York's Addleton Academic Publishers. 2012

2. Манойло А. В. Роль стратегий управмяемого хаоса в формировании нового миропоряАка // Право и политика.— 2014.— 5. — C. 638-651. DOI: 10.7256/1811-9018.2014.5.11816.

\section{REFERENCES (TRANSLITERATED)}

1. Anis H. Bajrektarevic. Is There Life after Facebook? New York's Addleton Academic Publishers. 2012

2. Manoilo A. V. Rol' strategii upravlyaemogo khaosa $\mathrm{v}$ formirovanii novogo miroporyadka // Pravo i politika. — 2014. - 5. - C. 638-651. DOI: 10.7256/1811-9018.2014.5.11816. 